Syntax Literate : Jurnal Ilmiah Indonesia p-ISSN: 2541-0849

e-ISSN : 2548-1398

Vol. 5 No. 3 Maret 2020

\title{
FENOMENA KETERBUKAAN KELOMPOK MINORITAS DALAM BERKOMUNIKASI DI MEDIA SOSIAL (STUDI PADA KELOMPOK MINORITAS LGBT DI MEDIA SOSIAL INSTAGRAM)
}

\section{Agus Salim}

Universitas Nasional (UNAS) Jakarta

Email: agussalimunas@gmail.com

\section{Abstract}

Social media start from facebook, youtube, instagram or whatsapp and many more, has became a part of daily life in the public, starts sharing information even just establishing communication. But impact of the rise of social media as information exchange who circulating sometimes is doubted the truth, even social media is used as a place to make utterances of hatred towards certain minority groups, namely LGBT. Teori Spiral of Silence or Spiral silence that has been felt by minority groups, their existence was silent without being able to issue opinions to avoid the fear of being isolated from the majority group. For minority groups, the majority opinion does not need to be refuted, because it can create debate to cause violence on minority groups. Now, Social media can be used by minority groups to voice their aspirations, which have so far only been buried. Although the impact they will receive blasphemy, but because through social media, they can understand the blasphemy because for minority groups like LGBT, express opinions and channel his voice is more important.

Keywords: Social Media, LGBT, Minority Group Openness.

\begin{abstract}
Abstrak
Media sosial mulai dari facebook, youtube, instagram maupun whatsapp dan banyak lagi, sudah menjadi bagian dalam kehidupan sehari-hari bermasyarakat, mulai saling berbagi informasi bahkan hanya sekedar menjalin komunikasi. Namun dampak dari maraknya media sosial sebagai pertukaran informasi yang cepat membuat informasi yang beredar kadang diragukan kebenarannya, bahkan media sosial dijadikan tempat untuk membuat ujaran kebencian terhadap kelompok minoritas tertentu, yakni LGBT. Teori Spiral of Silence, atau Spiral keheningan yang selama ini dirasakan oleh kelompok minoritas, dimana keberadaan mereka hanya diam saja tanpa bisa mengeluarkan pendapat untuk menghindari rasa ketakutan akan terisolasi dari kelompok mayoritas. Bagi kelompok minoritas pendapat mayoritas tidak perlu disanggah, karena dapat menciptakan perdebatan hingga menimbulkan kekerasan pada kelompok minoritas. Media sosial kini dapat dimanfaatkan oleh kelompok minoritas untuk menyuarakan aspirasinya yang selama ini hanya di pendam. Walau dapaknya mereka akan menerima hujatan, namun karena melalui media sosial, hujatan tersebut dapat mereka maklumi karena bagi kelompok minoritas seperti LGBT, menyampaikan pendapat dan menyaluran suaranya adalah hal yang lebih penting.
\end{abstract}

Kata kunci: Media Sosial, LGBT, Keterbukaan Kelompok Minoritas. 


\section{Pendahuluan}

Media massa berkembang begitu cepat (Nuruzzaman, 2018), salah satunya adalah media sosial. Media sosial sudah menjadi bagian dalam kehidupan dan tidak bisa terpisahkan dari setiap kegiatan sehari-hari. Semua kalangan mulai dari anak-anak, remaja, hingga dewasa menjadikan media sosial sebagai alat komunikasi yang efektif, rasanya tidak ada orang yang tidak memiliki akun di media sosial, walau hanya dalam bentuk email pun bisa dikategorikan bahwa media sosial memiliki peranan yang penting dan menjadi satu kebutuhan dalam kehidupan bersosial di masyarakat, maupun dalam sebuah kelompok-kelompok.

Facebook, twitter, instagram, youtube, whatsapp dan masih banyak lagi aplikasiaplikasi media sosial yang menjadi perantara sebagai alat dalam menjalin komunikasi. Dikutip dari websindo.com jumlah pengguna media sosial aktif per januari 2019 mencapai seratus lima puluh juta pengguna, dan jika di persentasekan mencapai $56 \%$ pengguna dengan mengakses melalui mobile phone sekitar seratus tiga puluh juta dan jika di persentasikan maka mencapai $48 \%$ pengguna media sosial yang aktif mengakses memalui mobile phone.

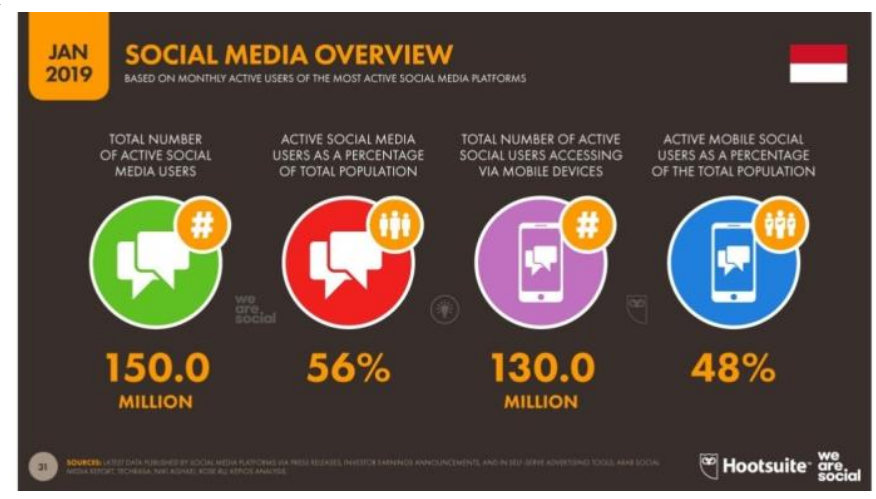

\section{Gambar 1 persentase jumlah pengguna media sosial}

Persentase jumlah pengguna media sosial akan terus meningkat seiring makin meningkatnya kebutuhan seseorang dalam menjalin komunikasi ke lingkungan sosialnya. Mudahnya penggunaan serta akses internet yang belakang ini menjamurnya hotspot-hotspot gratis yang bertebaran di lingkungan sekolah, pusat perbelanjaan serta sarana umum dimana banyak orang-orang berkumpul.

Meningkatnya jumlah pengguna media sosial maka tidak heran jika semua platform penyedia jasa media sosial lebih fokus untuk meningatkan performa serta tampilan media sosial dari masing-masing platform tersebut agar makin mudah dan pengguna tetap menggunakan aplikasinya.

Jumlah aplikasi media sosial yang semakin beragam, memungkinkan pengguna untuk memilih media sosial yang sesuai dan banyak digunakan oleh kelompoknya, misal pada whatsapp yang merupakan aplikasi wajib dan sudah pasti tersedia di setiap smartphone, serta penggunaan yang mudah dan dengan biaya yang cukup murah membuat aplikasi ini begitu digandrungi oleh setiap orang dalam melakukan komunikasi dengan teman atau kelompoknya, namun berdasarkan data yang penulis 
ambil dari websindo.com per Januari 2019, aplikasi yang banyak penggunanya adalah youtube, karena youtube merupakan media sosial yang lebih menggunggulkan tampilan dengan video-videonya. Selain itu pengguna yang menjadi kontribusi tetap video-video di youtube maka akan mendapatkan imbalan sejumlah uang, untuk itu banyak anakanak remaja saat ini berlomba-lomba menjadi seorang youtuber yakni sebutan bagi pengguna aplikasi youtube yang turut berkontribusi membagikan video yang mereka buat.

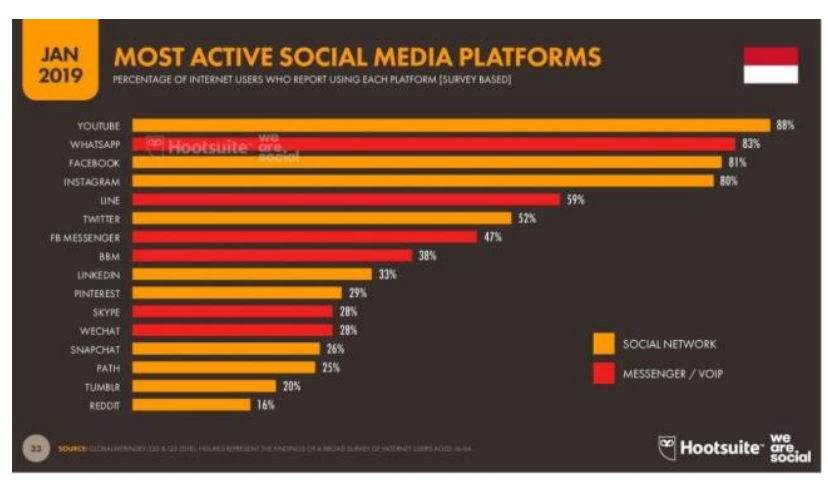

Gambar 2 most active social media platforms

Menjadikan media sosial sebagai sarana berbagi informasi dan menjalin komunikasi, menjadikan media sosial sebagai sarana menyebar berita bohong (hoax), menebar kebencian dan menjadi alat provokasi yang paling efektif karena jangkauannya yang cukup luas ke lapisan masyarakat. Beberapa kelompok minoritas yang sebelum munculnya media sosial hanya bungkam jika ada informasi yang tidak sesuai karena merasa takut dan merasa kecil dan hanya mengikuti suara mayoritas, kali ini turut bersuara menyampaikan ketidak setujuannya.

Kelompok yang selama ini hanya diam dan tidak berani menyampaikan pendapatnya atau dalam teori komunikasi disebut sebagai spiral of silence, merupakan kelompok minoritas, mereka hanya akan diam dan setuju saja dengan apa yang disampaikan oleh kalangan mayoritas, karena jika menyampaikan ketidak setujuan maka akan mendapat tekanan-tekanan.

Media sosial saat ini dijadikan sebagai tempat kelompok minoritas yang selama ini hanya diam, turut serta menyuarakan suaranya, sehingga dalam media sosial kelompok minoritas menjadi samar, karena dalam media sosial yang terjadi hanyalah kelompok pro dan kontra saat menyampaikan pendapatnya. Terjadi pergeseran dari pola komunikasi sejak media sosial dijadikan sebagai sarana berkomunikasi, menyampaikan pendapat serta berbagi informasi.

Seperti screenshot dari akun instagram bernama@fellfel yang membahas LGBT, terlihat dari komentar mayoritas yang tidak mendukung LGBT, namun ada salah satu komentar seperti memberi dukungan dari topik yang diangkat akun tersebut, lantas saja komentar yang memberikan dukungan akan eksistensi LGBT tidak lepas dari hujatan akun lain yang mengikuti diskusi tersebut. 
Agus Salim

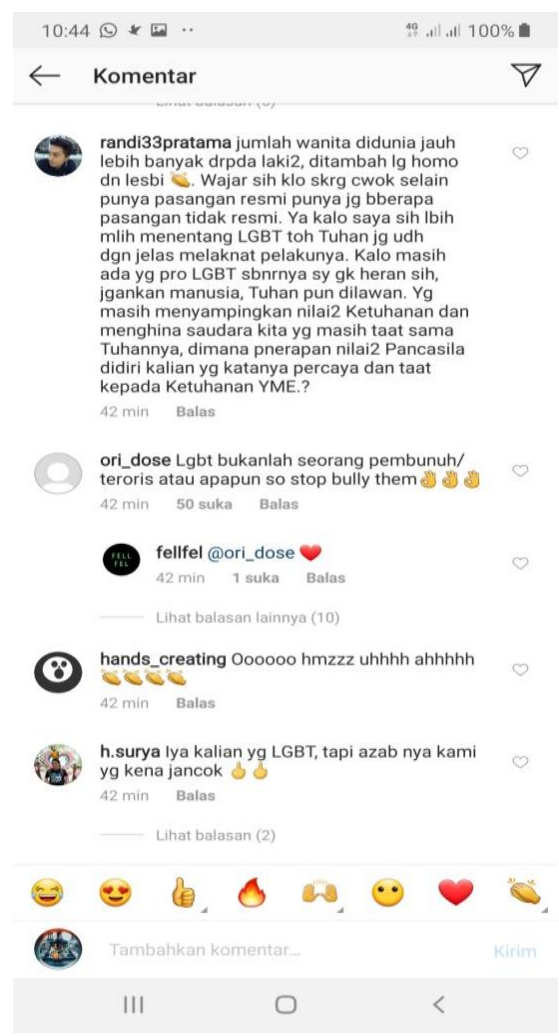

\section{Gambar 3 screenshot komentar pada Instagram}

Kelompok minoritas sebelum adanya media sosial hanya diam dan mengikuti apa yang mayoritas sampaikan, walau ada ketidaksetujuan dari minoritas, hanya dapat menyampaikan ke sesamanya saja, namun setelah adanya media sosial kaum minoritas tidak diam, dan berani mengutarakan pendapatnya, walau mereka sadari akan mendapat hujatan dan kalimat-kalimat tidak pantas dari kelompok mayoritas.

Kelompok minoritas merupakan kelompok dimasyarakat yang keberadaannya kadang menjadi sebuah pertentangan karena memiliki perbedaan dari kelompok mayoritas di masyarakat, kelompok minoritas kadang termarjinalkan di lingkungaannya sendiri. Adanya perbedaan sudut pandang, sikap maupun prilaku dikehidupan bermasyarakat.

Kelompok minoritas yang dimaksudkan disini adalah Lesbian, Gay, Biseksual, dan Transgender atau disingkat LGBT. Keberadaan mereka sangat bertentangan di masyarakat terkait orientasi seksual yang mereka miliki berbeda dengan masyarakat pada umumnya, stigma negatif yang melekat terhadap keberadaan mereka sehingga sebagian besar masyarakat di Indonesia memandang bahwa LGBT adalah acaman bagi masyarakat yang lebih di dominasi oleh heteroseksual.

BBC News Indonesia mengungkapkan berdasarkan survei Saiful Mujani Research and Consulting (SMRC) terkait Kontroversi Publik mengenai LGBT di Indonesia yang dilakukan sebanyak tiga kali, yaitu pada Maret 2016 dan Desember 2017, masyarakat yang memandang kelompok LGBT sebagai ancaman meningkat. Pada periode survei terakhir, sekitar 46,2\% responden menganggap LGBT cukup mengancam, sementara $41,4 \%$ lainnya menyatakan sangat mengancam. Bahkan dalam 
kategori lainnya, 41,1\% responden menilai kelompok LGBT tidak berhak hidup di Indonesia. (bbc.com 4 April 2019). LGBT di sangat ditentang keberadaannya di Indonesia, mereka diperlakukan seperti kriminal, seperti yang terjadi di wilayah Aceh, seorang LGBT di pangkas rambutnya karena melakukan kegiatan LGBT.

Survei diatas cukup menjelaskan mengapa kelompok minoritas seperti LGBT lebih memilih diam, dan lebih menuruti pendapat dari kelompok mayoritas, dalam lingkungan masyarakat keberadaan LGBT tidak terlalu mencolok, lain halnya jika di media sosial, banyak para pelaku LGBT secara terang-terangan mengakui bahwa dirinya menjadi bagian dalam kelompok LGBT.

Berdasarkan fenomena munculnya sikap kelompok minoritas untuk menunjukkan eksistensinya di dorong oleh merebaknya aplikasi-aplikasi sosial media di berbagai kalangan untuk berkomunikasi dan berbagi informasi, maka penulis mencoba mengungkap fenomena dimana kelompok minoritas seperti LGBT tidak hanya diam, namun dapat mengungkapkan pendapatnya walau hanya melalui media sosial seperti di Instagram.

\section{Metode Penelitian}

Dalam mencari jawaban atas fenomena yang penulis angkat, maka penulis akan menggunakan Metode Penelitian kualitatif karena memerlukan data yang dikumpulkan untuk menjawab fenomena keterbukaan kelompok minoritas dalam berkomunikasi di Media Sosial. Adapun jenis penelitian yang peneliti gunakan untuk mengungkap fenomena ini adalah penelitian deskriptif.

Peneliti menggunakan model penelitian deskriptif yang mengemukakan bahwa ditinjau dari jenis masalah yang diselidiki, teknik dan alat yang digunakan, serta tempat dan waktu (Nazir, 1988). Jenis penelitian deskriptif yang peneliti gunakan berupa kajian pustaka, menurut (Kartono, 1980) bahwa tujuan penelitian perpustakaan adalah untuk mengumpulkan data dan informasi dengan bantuan bermacam-macam material yang ada di perpusatakaan, hasilnya dijadikan fungsi dasar dan alat utama pagi praktek penelitian di lapangan. Sehingga untuk mengetahui timbulnya sebuah fenomena yang terjadi di kelompok minoritas yakni kelompok minoritas LGBT dalam menyampaikan pendapat di media sosial terkait ketidaksetujuannya yang selama ini hanya terdiam, kini berani terbuka dalam menyampaikan eksistensi mereka.

\section{Hasil dan Pembahasan}

\section{Fenomena}

Kamus Besar Bahasa Indonesia (KBBI) menerangkan bahwa fenomena merupakan hal-hal yang dapat disaksikan dengan pancaindra, dan dapat diterangkan serta dinilai secara ilmiah, seperti fenomena alam; gejala; lalu dalam KBBI juga menerangkan bahwa fenomena adalah orang (kejadian, benda, dsb) yang menarik perhatian atau luar biasa sifatnya; sesuatu yg lain dp yg lain; fakta; kenyataan.

Menurut (Ilmawati Fahmi Imron dan Aka, 2018) fenomena sosial adalah semua prilaku yang dipengaruhi atau mempengaruhi dilakukan oleh seseorang 
maupun kelompok tertentu dari/atau terhadap seseorang atau kelompok lain. Fenomena sosial dapat diartikan sebagai peristiwa yang terjadi dan dapat diamati dalam kehidupan bermasyarakat. Fenomena sosial terjadi ketika manusia menganggap segala sesuatu yang dialaminya adalah sebuah kebenaran mutlak. Menurut Soekanto dalam (Ilmawati Fahmi Imron dan Aka, 2018) mendefinisikan bahwa fenomena sosial merupakan masalah sosial yang berupa ketidaksesuaian antara masyarakat atau unsur-unsur kebudayaan yang membahayakan suatu kehidupan kelompok sosial.

Bertolak dari pendapat diatas maka dapat disimpulkan bahwa fenomena merupakan sebuah peristiwa yang terjadi di lingkungan sosial dimana hal tersebut dapat mempengaruhi seseorang atau kelompok tertentu dan dapat diamati di lingkungan sosial. Bila dikaitkan dengan permasalahan yang penulis angkat, maka pengungkapan ketidaksetujuan dari kelompok minoritas merupakan sebuah fenomena dalam lingkungan sosial. Awalnya keberadaan kelompok minoritas LGBT di masyarakat sangat ditentang, bahkan hingga saat ini, namun media sosial yang berkembang di era ini memfasilitasi kelompok minoritas tersebut untuk bersuara.

Meskipun penyampaian tersebut disampaikan melalui media sosial, setidaknya telah terjadi pergeseran nilai terhadap teori spiral of silence yang selama ini diartikan sebagai kelompok sunyi atau diam dan hanya menuruti pendapat kelompok mayoritas, namun faktanya saat ini dimana media sosial telah menjadi bagian kehidupan di masyarakat, kelompok minoritas dapat menyampaikan pendapatnya yang mereka sadari bertentangan dengan pendapat kelompok mayoritas di masyarakat.

\section{Media Sosial}

Media sosial bisa dilihat dari perkembangan bagaimana hubungan individu dengan perangkat media. Karakteristik kerja komputer dalam Web 1.0 berdasarkan pengenalan individu terhadap individu lain (human cognition) yang berada dalam sebuah sistem jaringan, sedangkan Web 2.0 berdasarkan bagaimana individu berkomunikasi (human communication) dalam jaringan antarindividu. Dalam Web 3.0 karakteristik teknologi dan relasi yang terjadi terlihat dari bagaimana manusia (users) bekerja sama (human co-operation), Fuch dalam (Nasrullah, 2017).

Media sosial dapat dikatakan sebagai munculnya media baru untuk menyampaikan pesan dari komunikator ke komunikan, yang sebelumnya menggunakan media konvensional seperti pesawat telepon ataupun kertas surat, kini penyampaian pesan bisa dilakukan dengan menggunakan media sosial sebagai dampak munculnya teknologi internet yang membuat setiap orang dapat berkomunikasi secara global tanpa batas.

Walther dalam (Ibrahim \& Akhmad, 2014) menggunakan istilah bagi seseorang yang merasa komunikasi melalui media sosial lebih menarik dari pada komunikasi langsung tatap muka (face to face communication) dengan menggunakan istilah komunikasi hiperpersonal (hyperpersonal communication), 
untuk menunjukkan aktivitas komunikasi sosial dengan perantaraan komputer atau smartphone yang dianggap lebih memikat daripada komunikasi langsung. Tanpa ada batasan inilah sehingga penyampaian informasi kadang bersifat menghasut, sehingga media sosial digunakan juga sebagai media penyampaian berita palsu atau hoax serta digunakan sebagai media untuk menyebar hasutan dan provokasi yang menyulut kebencian antar kelompok satu dengan kelompok lain.

Walau di Indonesia memiliki Undang-Undang Informasi Transaksi Elektronik (ITE), yang mengatur lalu lintas komunikasi dan informasi yang tersebar di media sosial namun tidak akan membuat jera seseorang untuk menyebar berita palsu dan menebar kebencian. Protes dan cacian kerap mengisi ruang-ruang komentar di media sosial mengenai eksistensi kelompok minoritas yakni LGBT. Seperti yang tercantum dalam UU ITE Pasal 28 ayat (2) Undang-Undang nomor 11 Tahun 2008 yang berbunyi "Setiap orang dengan sengaja dan tanpa hak menyebarkan informasi yang ditujukan untuk menimbulkan rasa kebencian atau permusuhan individu dan/atau kelompok masyarakat tertentu berdasarkan atas suku, agama, ras dan antargolongan (SARA) sebagaimana dimaksud dalam Pasal 28 ayat (2) dipidana dengan pidana penjara paling lama 6 (enam) tahun dan/atau denda paling banyak Rp. 1 Miliar".

Meskipun pemerintah telah menerapkan Undang-Undang Informasi Transaksi Elektronik (ITE) untuk menjerat pengguna media sosial agar tidak menyebarkan kebencian terhadap golongan tertentu, namun komentar-komentar di media sosial yang berisi cacian dan ujaran kebencian tetap saja mewarnai topik yang membahas mengenai LGBT. Namun, munculnya media sosial juga dimanfaatkan beberapa kelompok minoritas yang selama ini bungkam, berani menyampaiakan aspirasinya, walau mereka tahu akan mendapat cercaan dan katakata tidak pantas dari kelompok mayoritas, namun hal tersebut tidak menghancurkan tekad mereka untuk menyatakan eksistensinya, dalam hal ini kelompok minoritas Lesbian, Gay, Biseksual, dan Transgender atau disingkat LGBT.

Instagram merupakan aplikasi media sosial yang peneliti gunakan untuk mendapatkan sample penelitian, peneliti dapat melakukan tangkapan layar (Screenshot) yang sesuai dengan permasalahan yang peniliti angkat, karena instagram merupakan salah satu aplikasi yang paling diminati oleh pengguna internet untuk membuktikan bahwa media sosial kini sudah menjadi media efektif kelompok minoritas yang selama ini hanya diam dan mengikuti pendapat mayoritas saja, namun kali ini kelompok minoritas dapat menunjukkan eksistensinya ke khalayak mengenai keberadaan mereka, yang bangga menjadi bagian LGBT.

Seperti tangkapan layar berikut, yang meng-gambarkan eksistensi kelompok minoritas LGBT menyampaikan aspirasinya bahwa mereka juga punya hak, gambar tersebut peneliti ambil dari akun instagram @ generasipelangi: 




Sumber: Instagram akun @generasipelangi

\section{Gambar 4 screenshot postingan pada Instagram}

\section{Kelompok Minoritas Lesbian, Gay, Biseksual, dan Transgender (LGBT)}

Singkatan LGBT merupakan istilah yang digunakan pada awal tahun 90-an sampai sekarang. LGBT diambil dari singkatan LGB yang awal mulanya digunakan sebagai pengganti ungkapan 'gay community' (Komunitas Gay). Dewasa ini LGBT dipakai untuk menunjukkan seseorang atau siapapun yang memiliki perbedaan orientasi seksual dan indentitas gender berdasarkan kultur tradisional, yaitu: heteroseksual (Sinyo, 2014).

Ramainya pemberitaan selebritis Lucinta Luna yang menolak dikabarkan sebagai wanita transeksual sempat menghebohkan pemberitaan di media sosial maupun media konvensional, meskipun bukti-bukti kuat yang membenarkan bahwa Lucinta Luna adalah wanita transeksual namun tetap menolak sehingga muncullah hujatan-hujatan kebencian yang berimbas kepada kelompok LGBT.
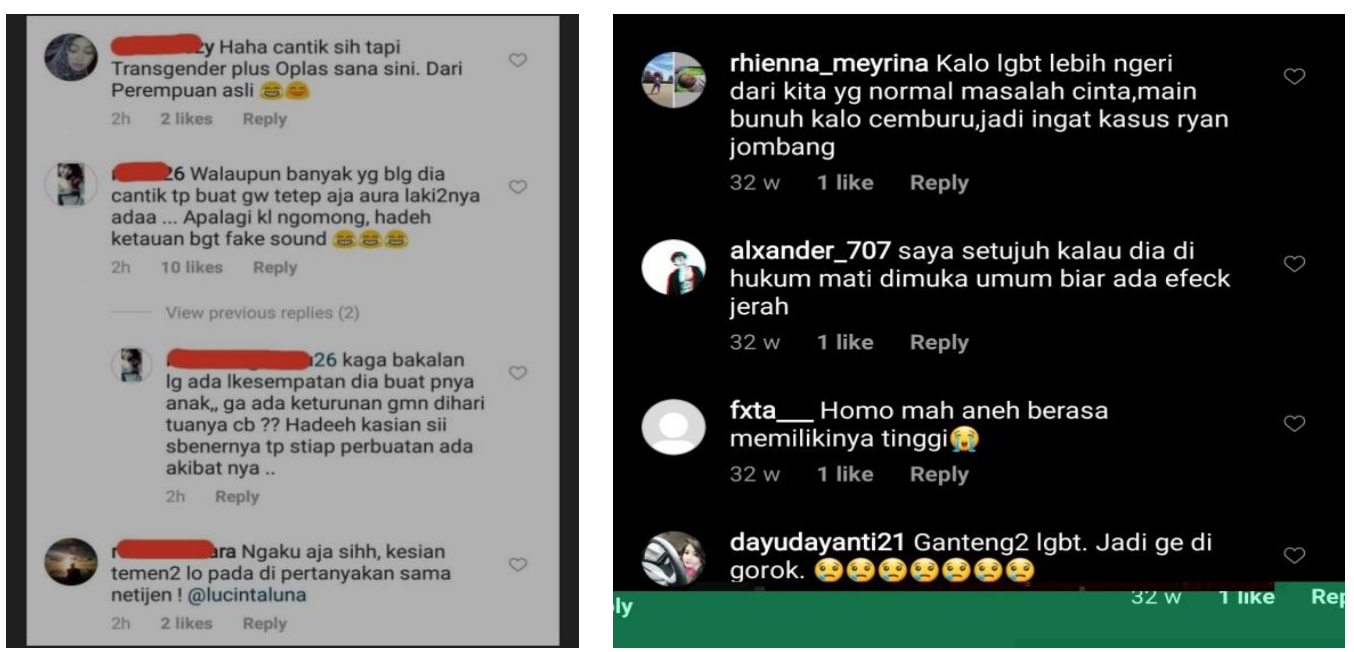

Sumber: Akun Instagram @tribunstyle 


\section{Gambar 5 screenshot komentar terhadap seorang artis}

Tidak hanya sebatas pemberitaan yang terkait penolakan Lucinta Luna sebagai wanita transeksual, namun juga tindakan-tindakan kriminal yang jika dilakukan oleh kelompok LGBT maka masyarakat pun beramai-ramai menghujat bukan hanya kepada tindakan pelaku namun juga ke orientasi seksual pelaku, meskipun orientasi heteroseksual pun juga melakukan tindakan keriminal. Seperti komentar terhadap kasus pembunuhan guru tari Budi Hartanto yang melibatkan asmara sesama jenis.

Munculnya hinaan serta cacian yang diterima oleh kelompok minoritas LGBT semakin menyudutkan keberadaan mereka, sehingga kelompok minoritas LGBT merasa perlu untuk berpendapat dan mengungkapkan eksistensi mereka, dan menjelaskan perasaan yang mereka rasakan sebagai LGBT, walau mereka sadari mereka tetap akan di sudutkan.

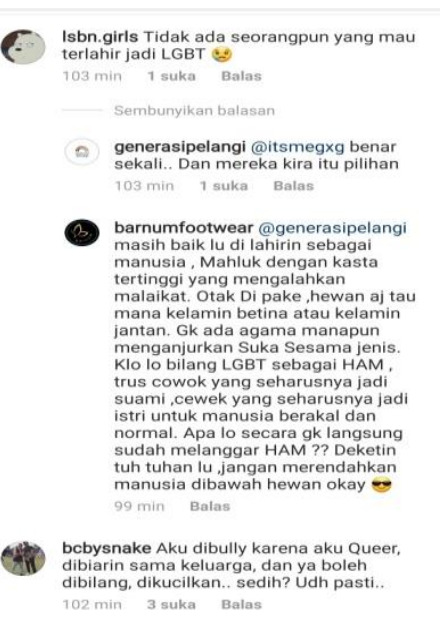

Sumber: Instagram akun @ generasipelangi

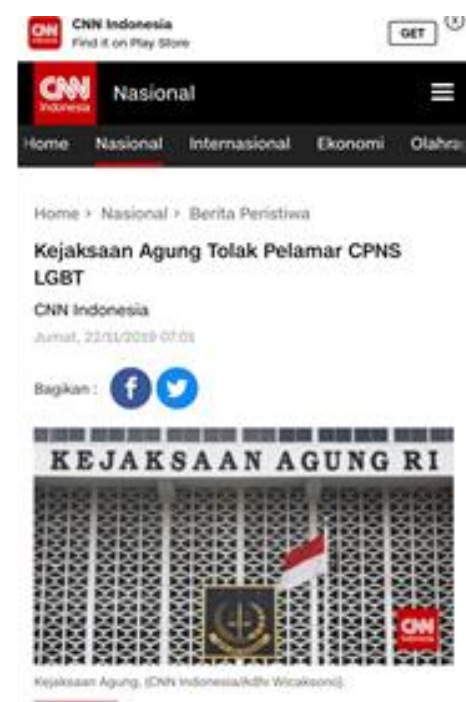

Sumber: cnnindonesia.com

\section{Gambar 6 screenshot bulliying kasus LGBT}

Diskriminasi terhadap kelompok minoritas seperti LGBT saat ini masih tetap terjadi, walaupun mereka sudah berani buka suara dan menyatakan orientasi seksualnya, namun bukan berarti masyarakat Indonesia bisa menerima keberadaan mereka, seperti yang terjadi saat ini dimana banyak larangan LGBT ikut serta dalam mengikuti tes masuk sebagai Calon Pengawai Negeri Sipil (CPNS), seperti yang dilansir dari CNN Indonesia tanggal 22 November 2019, bahwa Kejaksaan Agung Menolak Pelamar CPNS LGBT.

\section{Teori Spiral of Silence}

Teori spiral of silence merupakan teori yang digunakan untuk menggambarkan kelompok minoritas yang hanya terdiam saat ada pendapat atau sesuatu yang bertentangan dengan pandangan atau hati nurani mereka, kelompok minoritas terpaksa diam karena merasa tidak ada dukungan, dan hanya menjadi 
pengikut saja terhadap kelompok mayoritas. Berikut gambaran Spiral of Silence menurut Neumann dalam (Rusliana, Poppy dan Lestari, 2019)

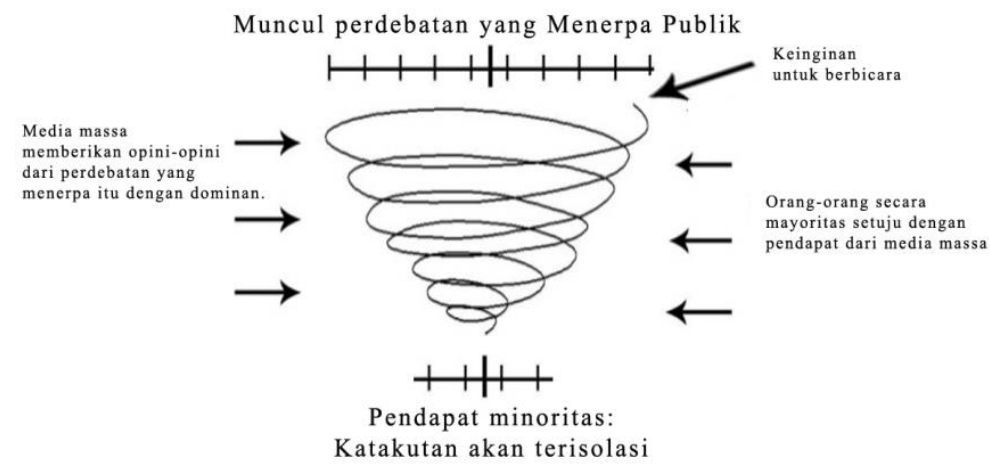

Gambar 7 Spiral of Silence

Berdasarkan gambar di atas dapat terlihat bahwa menurut pendapat minoritas: seseorang yang tadi ingin beropini, menjadi menahan opini itu, karena terpaku pendapat dari publik yang mayoritas dan media massa yang berbeda dengannya. Jika tetap memaksakan maka ada kemungkinan akan terisolasi dari kelompok sosialnya. Spiral of Silence merupakan sebuah teori media yang memberikan perhatiannya lebih pada pandangan kelompok mayoritas dan menekan pandangan minoritas, (West, Richard dan Turner, 2013) menyatakan bahwa media akan berfokus lebih pada pandangan kelompok mayoritas, dan meremehkan pandangan kelompok minoritas. Mereka yang minoritas akan menjadi lebih tidak asertif dalam mengkomunikasikan opini mereka, dan karenanya menyebabkan munculnya sebuah spiral komunikasi yang bergerak ke bawah.

Teori ini menjelaskan bahwa setiap orang memiliki pendapat masingmasing tentang suatu isu, tetapi setiap orang memiliki rasa takut untuk mengemukakan pendapatnya. Dalam teori keheningan ini kita akan tahu bahwa suara mayoritas akan membungkam suara minoritas hingga tidak mampu berkatakata (Oktarina \& Abdullah, 2017).

Perlahan tapi pasti suara LGBT yang selama ini tertutup oleh suara kelompok mayoritas telah bergeser secara perlahan sejak maraknya media sosial, banyaknya akun-akun dimana pemilik akun tersebut merupakan seorang LGBT sudah mulai berani menunjukkan eksistensinya dan memiliki banyak pengikut (followers). Seperti akun @mimiperi, atau@ @lucintaluna selain itu akun-akun komunitas LGBT pun marak di media-media sosial khususnya instagram seperti akun@generasipelangi, @beranibangga dan lain sebagainya. 

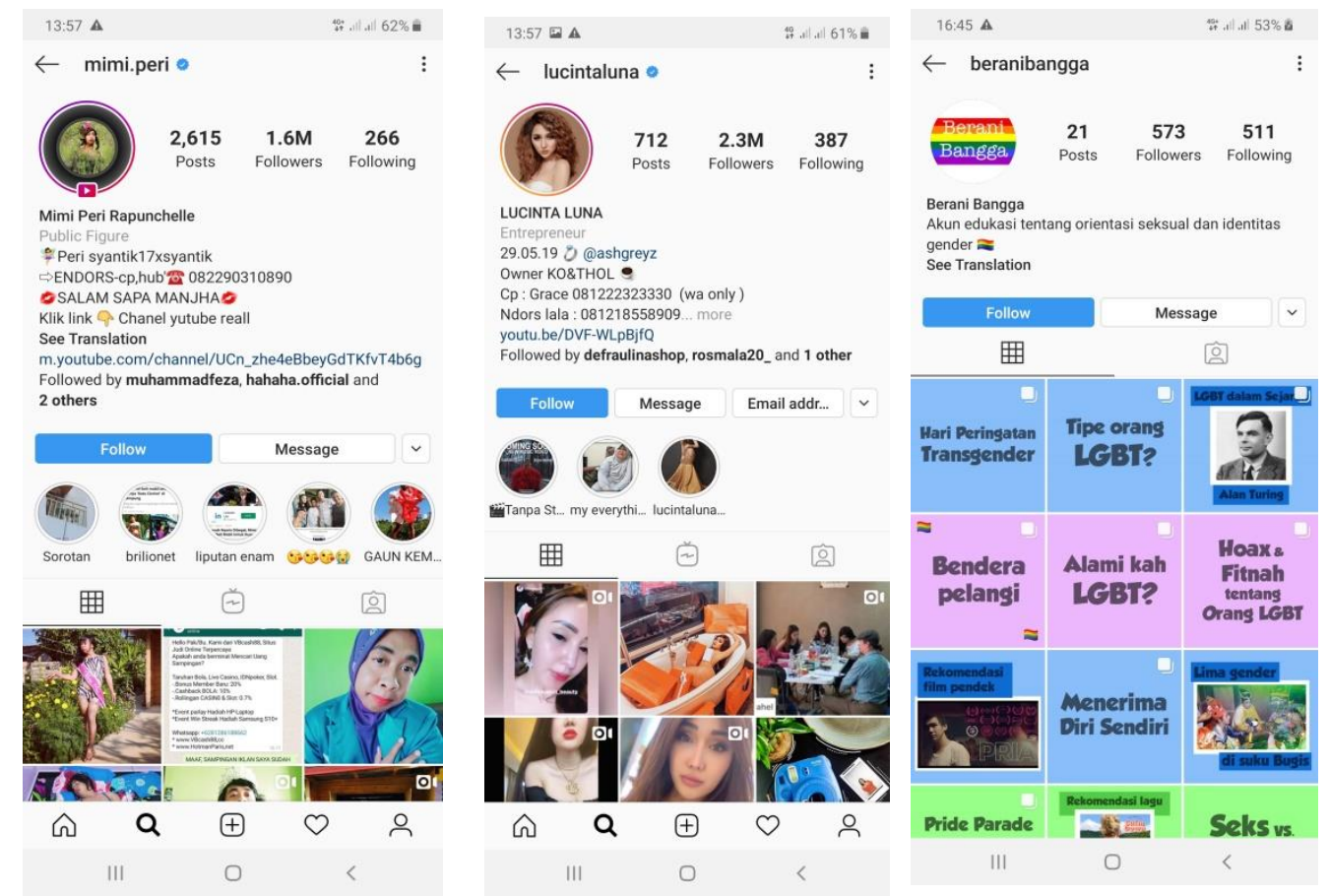

\section{Gambar 8 screenshot postingan selebgram}

Potongan-potongan gambar hasil screenshot tersebut merupakan akun-akun seorang LGBT dan juga akun komunitas LGBT di instagram. Hal ini merupakan bukti bahwa kelompok minoritas LGBT saat ini sudah berani untuk mengaktualisasikan diri mereka di tengah masyarakat yang lebih mengakui orientasi heteroseksual. Teori Spiral of Silence belakangan ini menjadi samar karena dalam media sosial dimana kelompok minoritas yang sepatutnya hanya diam, kini berani bersuara. Setiap komentar bahkan hanya terjadi perdebatan antara pihak yang pro dan kontra akan eksistensi LGBT, kelompok minoritas LGBT tidak lagi mengikuti suara kelompok mayoritas di masyarakat, kali ini mereka berusaha memperjuangkan hak mereka atas keberadaannya di tengah masyarakat.

\section{Kesimpulan}

Media sosial telah menjadi bagian dari kehidupan di masyarakat, setiap orang dipastikan memiliki akun di media sosial bahkan berdasarkan data statistik pengguna media sosial aktif per januari 2019 mencapai seratus lima puluh juta pengguna. Tingginya pengunaan media sosial sehingga penggunaan media sosial kadang tidak terkontrol dalam menjalin komunikasi, apalagi dalam kolom komentar dimana pembahasan kadang menyinggung sebuah kelompok minoritas, dalam hal ini LGBT.

Teori Spiral of Silence menggambarkan bahwa kelompok minoritas akan bungkam dan tidak berani mengutarakan pendapat sehingga hanya mengikuti suara mayoritas di masyarakat, hal ini dilakukan agar mereka terhindar dari konflik. Seiring perkembangan teknologi komunikasi, dimana media sosial makin menjamur membuat 
jalinan komunikasi semakin mudah. Media sosial yang semakin menjamur di gunakan oleh kelompok minoritas untuk mengaktualisasikan diri mereka yang selama ini hanya bungkam dan menuruti apa yang dikehendaki oleh kelompok mayoritas.

Saat ini di media sosial seperti instagram menjadi salah satu media untuk kelompok minoritas yakni LGBT dalam mengaktualisasikan keberadaan mereka. Walaupun dalam kolom komentar dimana setiap topik yang membahas LGBT selalu mendapat pertentangan dari kelompok mayoritas, namun kelompok LGBT sudah bisa membuka suara dan berupaya membela hak mereka walau disadari akan mendapat pertentangan.

Hal ini membuktikan bahwa kelompok minoritas mulai berani bersuara, berbeda saat media sosial belum ada. Eksistensi keberadaan kelompok LGBT walau masih mendapat berbagai pertentangan dari kelompok mayoritas, namun saat ini mereka dapat mengaktualisasikan diri mereka di media sosial. Segala macam pertentangan dan penolakan akan keberadaan kelompok LGBT masih tetap ada, namun kelompok LGBT berusaha menunjukkan eksistensinya, sehingga terkadang menjadi pro dan kontra mengenai keberadaan kelompok minoritas seperti LGBT ini sehingga mengaburkan arti dari kelompok minoritas yang hanya diam dan menuruti pendapat kelompok mayoritas agar terhindar konflik dan terisolasi dari kelompok mayoritas seperti dalam teori komunikasi yakni Spiral of Silence. 
Fenomena Keterbukaan Kelompok Minoritas dalam Berkomunikasi di Media Sosial

\section{BIBLIOGRAFI}

Ibrahim, I. S., \& Akhmad, B. A. (2014). Komunikasi dan Komodifikasi: Mengkaji Media dan Budaya dalam Dinamika Globalisasi. Yayasan Pustaka Obor Indonesia.

Ilmawati Fahmi Imron dan Aka, K. A. (2018). Fenomena Sosial.

Kartono, K. (1980). Pengantar metodologi research sosial. Alumni.

Nasrullah, R. (2017). Peer Riview Etnografi Virtual Riset Komunikasi Budaya Sosioteknologi Di Internet (Reviewer 1). Simbiosa Rekatama Media.

Nazir, M. (1988). Metode Penelitian Hukum. Cet ke-3. Jakarta: Ghalia Indonesia.

Nuruzzaman, M. (2018). Terorisme dan Media Sosial Sisi Gelap Berkembangnya Teknologi Informasi Komunikasi. Syntax Literate; Jurnal Ilmiah Indonesia, 3(9), 61-76.

Oktarina, Y., \& Abdullah, Y. (2017). Komunikasi Dalam Perspektif Teori Dan Praktik. Deepublish.

Rusliana, Poppy dan Lestari, P. (2019). Teori Komunikasi. PT. RajaGrafindo Persada.

Sinyo. (2014). Anakku Bertanya Tentang LGBT, Jakarta. In PT. Elex Media Koputindo, Kompas Gramedia.

West, Richard dan Turner, L. H. (2013). Pengantar Teori Komunikasi: Analisis dan Aplikasi. Salemba Humanika. 